\title{
ANALISIS KESULITAN BELAJAR MATEMATIKA PADA SOAL HOTS MATERI BILANGAN BULAT SISWA KELAS IV SDN 1 GUNUNGSARI
}

\author{
Rizky Nuras Pratama ${ }^{1)}$, Ervina Eka Subekti ${ }^{2)}$, Yusuf Setia Wardana ${ }^{3)}$ \\ Universitas PGRI Semarang. \\ Corresponding author Email: rizkynuras1515@gmail.com
}

\begin{abstract}
Abstrak
Kata Kunci: Bilangan bulat, analisis kesulitan belajar, HOTS

Latar belakang dari penelitian ini adalah rendahnya nilai matematika pada soal HOTS materi bilangan bulat pada siswa kelas IV SDN 1 Gunungsari. Permasalahan dalam penelitian ini adalah bagaimanakah kesulitan yang dialami siswa dalam menyelesaikan soal HOTS materi bilangan bulat pada siswa kelas IV SD N 1 Gunungsari. Tujuan yang hendak dicapai dalam penelitian ini adalah mendeskripsikan kesulitan yang dialami siswa dalam menyelesaikan soal HOTS materi bilangan bulat pada siswa kelas IV SDN 1 Gunungsari Jenis penelitian ini adalah penelitian kualitatif Penelitian ini bersifatkualitatif, yaitu mendeskripsi datadata yang diperoleh di lapangan. Rancangan penelitian yang digunakan juga merupakan penelitian deskriptif kualitatif. Hasil penelitian ini adalah kesulitan belajar yang dialami siswa dalam menyelesaikan soal HOTS materi bilangan bulat adalah siswa kesulitan dalam memahami yang ditanyakan dalam soal dengan baik sehingga siswa kesulitan dalam mengaplikasikan rumus yang tepat untuk menyelesaikan soalnya dengan benar. Siswa juga kurang teliti dalam mengerjakan soal sehingga jawaban yang diperoleh kurang maksimal.
\end{abstract}

Keyword: Integer, learning difficulty analysis, HOTS
The background of this research is the low mathematics score of HOTS questions in integer material for the fourth-grade students of SDN 1 Gunungsari. The problem in this research is how the difficulties found in solving HOTS questions on integer material in grade IV SD N 1 Gunungsari? The objective that can be achieved in this study is to describe the difficulties of students in solving HOTS questions in integer material in grade IV SDN 1 Gunungsari. This type of research is qualitative research. Qualitative research, which describes the data obtained in the field. The research design used is also a qualitative descriptive study. The results of this study were the students' learning difficulties in solving HOTS questions in integer material were students having difficulty understanding what was being asked in the questions properly so that students had difficulty applying the right formula to solve the problem correctly. Students are also less careful in working on the questions so that the answers obtained are not optimal.

@ Inventa: Jurnal Pendidikan Sekolah Dasar Copy Right

\section{Pendahuluan}

\section{Pendidikan adalah proses}

pembelajaran bagi peserta didik untuk dapat mengerti, paham, dan membuat manusia lebih kritis dalam berpikir. Telah menjadi pengetahuan umum bahwa pendidikan adalah suatu bentuk investasi jangka panjang yang penting bagi seorang 
manusia di masa depannya. Pendidikan merupakan sebuah kebutuhan wajib bagi setiap manusia, sebab sebuah pendidikan akan menjadi sebuah senjata dan pertahanan pada diri manusia itu sendiri yang mampu membuka sebuah sejarah masa lalu dan diterapkan kembali di masa yang berbeda ataupun juga sebagai kompas kehidupan yang mengarahkan kemana arah langkah kehidupan manusia untuk mampu bertahan pada perubahan zaman (Eko, Jalil dan Faisol, 2019: 65).

Penting di era globalisasi yang penuh tantangan dan kompetisi, sehingga dapat menggali potensi-potensi yang dimiliki oleh peserta didik untuk berkembang menjadi lebih baik. Sebagaimana yang di definisikan dalam Undang-Undang Republik Indonesia Nomor 20 Tahun 2003 tentang Sistem Pendidikan Nasional bahwa:

Pendidikan adalah usaha sadar dan terencana untuk mewujudkan suasana belajar dan proses pembelajaran agar peserta didik secara aktif mengembangkan potensi dirinya untuk memiliki kekuatan spiritual keagamaan, pengendalian diri, kepribadian, kecerdasan, akhlak mulia, serta keterampilan yang diperlukan dirinya, masyarakat, bangsa, dan negara.

\section{Drijakara dalam Soegeng Ysh} (2016:42) pendidikan bertujuan untuk memanusiakan manusia, yaitu menjadikan manusia sebagai manusia; membentuk manusia seutuhnya, yaitu manusia terdidik, berpengetahuan luas dan mendalam, mampu mengembangkan dan mengendalikan emosinya, memiliki sikap dan kehendak yang kuat dan berketerampilan yang bermanfaat. Terkait dengan pentingnya pendidikan, salah satu cara untuk membentuk individu yang berkualitas adalah dengan mendorong siswa untuk meraih prestasi yang tinggi. Siswa sebagai penerus bangsa diharapkan mampu mengubah mutu pendidikan menjadi lebih baik. Peningkatan kualitas pendidikan bisa dilakukan dengan cara mengajarkan para siswa untuk mulai berpikir secara kritis dalam memecahkan masalah-masalah yang dihadapi.

Siswa sekolah dasar merupakan siswa yang masih membutuhkan perhatian besar dan rasa ingin tahu yang sangat tinggi. Bagi para guru disini merupakan ladang untuk mengeksplor kemampuan mereka dengan mencoba melatihkan kemampuan berpikir tingkat tinggi pada siswa sekolah dasar. Pada dasarnya keterampilan berpikir tingkat tinggi dapat diterapkan dalam berbagai disiplin ilmu salah satunya pelajaran matematika. Keunggulan keterampilan berpikir tingkat tinggi dapat menunjang prestasi akademik siswa (Conklin \& Manfro, 2012: 9). Ciri utama keterampilan berpikir tingkat tinggi 
adalah kritis dan kreatif (Conklin, 2012: 14).

Menrut M. Yusuf Setia Wardhana dan Silvia Trisnawati (2016) Berpikir kritis merupakan sebuah keterampilan kognisi seseorang untuk menanamkan sebuah situasi, masalah, pertanyaan, atau peristiwa agar dapat memberikan tanggapan dan keputusan. Melalui keterampilan kognisi yang dimiliki, seseorang dapat memecahkan sebuah masalah yang terjadi dalam kehidupannya. Menurut Resnick dalam Yoki Ariyana dkk (2019: 6) mendefinisikan bahwa keterampilan berpikir tingkat tinggi adalah proses berpikir kompleks dalam menguraikan materi, membuat kesimpulan, membangun representasi, menganalisis, dan membangun hubungan dengan melibatkan aktivitas mental yang paling dasar. High Order Thinking Skills ini meliputi kemampuan pemecahan masalah, kemampuan berpikir kreatif, berpikir kritis, kemampuan berargumen, dan kemampuan mengambil keputusan.

\section{Menurut Menurut Zaini (2015)} berpikir tingkat tinggi adalah keterampilan berpikir yang mengkombinasikan antar berpikir kritis dan berpikir kreatif. HOTS merupakan aktivitas berpikir siswa yang melibatkan level kognitif tingkat tinggi dari Taksonomi Bloom yang meliputi menganalisis, mengevaluasi, dan mencipta (Anderson \& Krathwohl, 2015:43). Tujuan utama dari High Order Thinking Skills adalah bagaimana meningkatkan kemampuan berpikir peserta didik pada level yang lebih tinggi, terutama yang berkaitan dengan kemampuan untuk berpikir secara kritis dalam menerima berbagai jenis informasi, berpikir kreatif dalam memecahkan suatu masalah menggunakan pengetahuan yang dimiliki serta membuat keputusan dalam situasisituasi yang kompleks (Saputra, 2016:9192).

Salah satu mata pelajaran yang menjadi kesulitan terbesar siswa pada umumnya adalah matematika. Depdiknas dalam (Susanto, 2013: 184) matematika berasal dari bahasa latin yaitu manthanein atau mathema yang berarti belajar atau suatu hal yang sedang dipelajari, sedangkan dalam bahas belanda, matematika memiliki arti wiskunde yang berarti ilmu pasti, yang semuanya berkaitan dengan penalaran. Secara umum, terdapat tiga materi pokok dalam pembelajaran matematika di SD. Materi-materi tersebut adalah bilangan, geometri dan pengukuran, serta pengolahan data. Materi pembelajaran yang diteliti dalam penelitian ini adalah bilangan. Konsep bilangan yang dibelajarkan di kelas IV semester II adalah bilangan bulat. 
Menurut Suparti, dkk dalam (Nariyah, 2016:48-50) mengemukakan bahwa bilangan bulat terdiri dari bilangan positif, nol dan bilangan bulat negatif. Bilangan-bilangan yang lebih besar dari nol disebut bilangan positif dan bilanganbilangan yang lebih kecil dari nol disebut bilangan negatif. mata pelajaran matematika khususnya operasi hitung bilangan bulat perlu diberikan kepada semua siswa mulai dari sekolah dasar untuk membekali mereka dengan kemampuan berpikir logis, analitis, sistematis, kritis, dan kreatif, serta kemampuan bekerjasama. Hal ini dilakukan agar siswa dapat menggunakannya sebagai dasar untuk memecahkan masalah dalam kehidupan sehari-hari. Akan tetapi, banyak siswa yang mengalami kesulitan dalam mempelajari operasi hitung bilangan bulat.

Ketidakmampuan siswa dalam menyelesaikan dan memahami dengan baik soal-soal bilangan bulat yang berupa soal HOTS karena dapat diketahui dari hasil pekerjaan siswa dalam mengerjakan soal. Hal ini disebabkan karena soal HOTS memiliki jalan yang kompleks dan kadang harus menentukan berbagai variabel terlebih dahulu sebelum dapat menyimpulkan jawabannya, dan siswa di SDN 1 Gunungsari belum bisa memahami konsep dengan baik sehingga siswa kesulitan dalam menentukan alur untuk mengerjakan soal HOTS tersebut.

Berdasarkan uraian di atas, mengenai kesulitan-kesulitan siswa dalam menyelesaikan soal-soal HOTS tentang materi bilangan bulat maka perlu dilakukan analisis kemampuan siswa dalam menyelesaikan soal matematika pada materi operasi bilangan bulat. Oleh karena itu dilakukan penelitian dengan judul, Analisis Kesulitan Belajar Pada Soal HOTS Materi Bilangan Bulat Siswa Kelas IV SD N 1 Gunungsari. Peneliti menggunakan metode penelitian deskriptif kualitatif dengan teknik analisis data yakni analisis kualitatif untuk menganalisis data. Analisi Isi kualitatif dapat mengidentifikasi pesan yang nampak dan tidak nampak dari dokumen yang sedang diteliti. Manfaat dari penelitian ini antara lain dapat diajukan sebagai bahan penelitian dimasa mendatang yang ingin mengetahui lebih lanjut mengenai kesulitan-kesulitan siswa dalam menyelesaikan soal HOTS tentang bilangan bulat. Selain itu, penelitian ini juga dapat dijadikan sebagai bahan informasi dan edukasi khalayak.

\section{Metode Penelitian}

Metode penelitian yang digunakan dalam penelitian ini menggunakan metode penelitian kualitatif. Pendekatan yang dilakukan adalah deskriptif kualitatif yang 
dilakukan dengan menguraikan fakta-fakta yang diperoleh dari sumber data. Penelitia dilaksanakan di SDN 1 Gunungsari Rembang Tahun Ajaran 2019/2020 dengan sasaran penelitian yaitu peserta didik kelas IV. Data yang diperoleh peneliti berupa hasil wawancara dan hasil analisis soal uraian yang dikerjakan oleh subjek penelitian siswa kelas IV SDN 1 Gunungsari. Peneliti menganalisis jawaban soal uraian dengan menggunakan indicator kesalahan menurut Newman.

Dalam penelitian kualitatif, peneliti adalah instrument utama. Instrumen bantu didalam ini adalah pedoman wawancara, tes berupa soal uraian, serta pedoman dokumentasi untuk mengumpulkan data tentang bagaimanakah kesulitan yang dialami siswa dalam menyelesaikan soal HOTS materi bilangan bulat pada siswa kelas IV SDN Gunungsari.

\section{Hasil Dan Pembahasan}

Dalam menentukan subjek penelitian, peneliti menggunakan data yang diperoleh dari hasil tes dan wawancara. Tes berupa soal uraian berjumlah 5 soal yang diberikan kepada siswa untuk mengetahui kesulitan siswa dalam menyelesaikan soal HOTS materi bilangan bulat. Tes diberikan kepada 10 orang peserta didik terpilih kelas IV SDN 01 Gunungsari Rembang yang terdiri dari 7 siswa berjenis kelamin perempuan dan 3 siswa berjenis kelamin laki-laki.

Adapun rincian masing-masing subjek yang terpilih, disajikan pada table berikut:

Table 1. Daftar subjek penelitian

\begin{tabular}{rlr}
\hline No. & \multicolumn{1}{c}{ Nama Siswa } & $\begin{array}{r}\text { Kode } \\
\text { Siswa }\end{array}$ \\
\hline 1. & Luthfiana Shafa & $\mathrm{S} 1$ \\
& Nur'aini & \\
\hline 2. & Putri Erni Setiani & $\mathrm{S} 2$ \\
\hline 3. & Nurul Sri Wahyuni & $\mathrm{S} 3$ \\
\hline 4. & Eva Khoirun Nisa & $\mathrm{S} 4$ \\
\hline 5. & Reza Aziz Sholohin & $\mathrm{S} 5$ \\
\hline 6. & Emas Putra Santoso & $\mathrm{S} 6$ \\
\hline 7. & Putri Erna Setiana & $\mathrm{S} 7$ \\
\hline 8. & Nur Eka Novita Sari & $\mathrm{S} 8$ \\
\hline 9. & Amanda Eva & $\mathrm{S} 9$ \\
\hline 10. & Putra Yoga Pamuji & $\mathrm{S} 10$ \\
\hline
\end{tabular}

terpilih kemudian diberikan soal matematika Higher Order Thinking Skills materi bilangan bulat, dimana hasil pekerjaan tersebut akan didapati kesalahankesalahan yang dilakukan. Kemudian untuk menelusuri lebih dalam kesalahan yang muncul maka peneliti melakukan wawancara dengan subjek.

Pengumpulan data dilakukan sesuai dengan instrumen pengumpulan data yang 
telah dipersiapkan. Data diambil pada guru dan peserta didik Kelas IV di SDN gunungsari 01 Rembang. Pada bagian ini akan dipaparkan data hasil penelitian yaitu data hasil wawancara dengan guru dan analisis kesalahan siswa dalam menyelesaikan soal Higher Order Thinking Skills materi bilangan bulat berdasarkan kriteria kesalahan Newman yang meliputi memahami masalah (comprehension), transformasi (transformation), keterampilan proses (process skill) dan penulisan jawaban (encoding). Data penelitian dianalisis melalui jawaban pada tes subjek dan transkip wawancara kepada subjek.

Table 2. Hasil analisis soal HOTS dengan panduan Newman subjek pertama

\begin{tabular}{rrrrr}
\hline No & \multicolumn{4}{c}{ Jenis Kesalahan } \\
\cline { 2 - 5 } & $\begin{array}{c}\text { Mema } \\
\text { hami } \\
\begin{array}{c}\text { Masal } \\
\text { ah }\end{array}\end{array}$ & $\begin{array}{c}\text { Transfo } \\
\text { rmasi }\end{array}$ & $\begin{array}{c}\text { Ketera } \\
\text { mpilan } \\
\text { Proses }\end{array}$ & $\begin{array}{c}\text { Penul } \\
\text { isan } \\
\text { Jawa } \\
\text { ban }\end{array}$ \\
\hline 1. & 4 & 4 & 4 & 4 \\
\hline 2. & 2 & 2 & 2 & 2 \\
\hline 3. & 4 & 4 & 4 & 4 \\
\hline 4. & 4 & 4 & 4 & 4 \\
\hline 5. & 2 & 2 & 2 & 2 \\
\hline $\begin{array}{l}\text { Rata } \\
\text { rata: }\end{array}$ & 3,2 & 3,2 & 3,2 & 3,2 \\
\hline
\end{tabular}

Deskripsi:

Berdasarkan hasil pekerjaan subjek 1 terlihat bahwa subjek 1 mengalami kesulitan mengerjakan soal nomer 2 dan nomer 5. Kesulitannya dipengaruhi oleh subjek 1 belum bisa memahami soal dengan baik sehingga subjek 1 salah dalam menentukan rumus yang akan digunakan untuk menyelesaikan soal sehingga jawannya tidak tepat.

Table 3. Hasil analisis soal HOTS dengan panduan Newman subjek kedua

\begin{tabular}{lcccc}
\hline $\begin{array}{c}\text { No } \\
\text { So } \\
\text { al }\end{array}$ & \multicolumn{4}{c}{ Jenis Kesalahan } \\
\cline { 2 - 5 } & $\begin{array}{c}\text { Mema } \\
\text { hami } \\
\text { Masal } \\
\text { ah }\end{array}$ & $\begin{array}{c}\text { Transfo } \\
\text { rmasi }\end{array}$ & $\begin{array}{c}\text { Ketera } \\
\text { mpilan } \\
\text { Proses }\end{array}$ & $\begin{array}{c}\text { Penul } \\
\text { isan } \\
\text { Jawa } \\
\text { ban }\end{array}$ \\
\hline 1. & 2 & 4 & 4 & 4 \\
\hline 2. & 4 & 2 & 2 & 2 \\
\hline 3. & 4 & 4 & 4 & 3 \\
\hline $\mathbf{4 .}$ & 4 & 4 & 2 & 2 \\
\hline 5. & 3 & 2 & 2 & 2 \\
\hline Rata & 3,4 & 3,2 & 3,5 & 2,6 \\
rata: & & & & \\
\hline Deskripsi: & & & \\
\hline
\end{tabular}

Berdasarkan hasil pekerjaan subjek 2 terlihat bahwa subjek 2 mengalami kesulitan mengerjakan soal nomer 2, 4 dan 5. Pada soal nomor 2 dan 5 kesulitannya dipengaruhi oleh subjek 2 belum bisa memahami soal dengan baik sehingga subjek 2 salah dalam menentukan rumus yang akan digunakan untuk menyelesaikan soal sehingga jawannya tidak tepat. Sedangkan pada soal nomor 4 siswa melakukan kesalahan dalam perhitungan karena siswa kurang teliti saat proses berhitung sehingga jawaban siswa kurang tepat. 
Table 4. Hasil analisis soal HOTS dengan panduan Newman subjek ketiga

\begin{tabular}{lcccc}
\hline No & \multicolumn{4}{c}{ Jenis Kesalahan } \\
\cline { 2 - 5 } $\begin{array}{c}\text { So } \\
\text { al }\end{array}$ & $\begin{array}{c}\text { Mema } \\
\text { hami } \\
\text { masal } \\
\text { ah }\end{array}$ & $\begin{array}{c}\text { Transfo } \\
\text { rmasi }\end{array}$ & $\begin{array}{c}\text { Ketera } \\
\text { mpilan } \\
\text { Proses }\end{array}$ & $\begin{array}{c}\text { Penul } \\
\text { isan } \\
\text { Jawa } \\
\text { ban }\end{array}$ \\
\hline 1. & 4 & 4 & 4 & 3 \\
\hline 2. & 4 & 2 & 2 & 2 \\
\hline 3. & 1 & 1 & 1 & 2 \\
\hline 4. & 4 & 1 & 1 & 2 \\
\hline 5. & 1 & 2 & 1 & 2 \\
\hline Rata & 2,8 & 2 & 1,8 & 2,2 \\
rata: & & & & \\
\hline Desk
\end{tabular}

Deskripsi:

Berdasarkan hasil pekerjaan subjek 3 terlihat bahwa subjek 3 mengalami kesulitan mengerjakan soal nomer 3, 4 dan 5. Pada soal nomor 3, 4 dan 5 kesulitannya dipengaruhi oleh subjek 3 belum bisa memahami soal dengan baik/sehingga subjek 3 jawabannya tidak tepat.

Table 5. Hasil analisis soal HOTS dengan panduan Newman subjek keempat

\begin{tabular}{lcccc}
\hline $\begin{array}{c}\text { No } \\
\text { So } \\
\text { al }\end{array}$ & \multicolumn{4}{c}{ Jenis Kesalahan } \\
\cline { 2 - 5 } & $\begin{array}{c}\text { Mema } \\
\text { hami } \\
\text { Masal } \\
\text { ah }\end{array}$ & $\begin{array}{c}\text { Transfo } \\
\text { rmasi }\end{array}$ & $\begin{array}{c}\text { Ketera } \\
\text { mpilan } \\
\text { Proses }\end{array}$ & $\begin{array}{c}\text { Penul } \\
\text { isan } \\
\text { Jawa } \\
\text { ban }\end{array}$ \\
\hline 1. & 4 & 2 & 1 & 2 \\
\hline 2. & 3 & 4 & 2 & 2 \\
\hline 3. & 4 & 4 & 4 & 3 \\
\hline 4. & 3 & 4 & 2 & 2 \\
\hline 5. & 3 & 2 & 2 & 2 \\
\hline $\begin{array}{l}\text { Rata } \\
\text { rata: }\end{array}$ & 3,4 & 3,2 & 2,2 & 2,2 \\
\hline
\end{tabular}

Deskripsi:
Berdasarkan hasil pekerjaan subjek 4 terlihat bahwa subjek 4 mengalami kesulitan mengerjakan soal nomer 1 dan 5. Pada soal nomor 1 dan 5 kesulitannya dipengaruhi oleh subjek 4 belum bisa memahami soal dengan baik sehingga subjek 4 salah dalam menentukan rumus yang akan digunakan untuk menyelesaikan soal sehingga jawannya tidak tepat.

Table 6. Hasil analisis soal HOTS dengan panduan Newman subjek kelima

\begin{tabular}{lc|c|cc}
\hline $\begin{array}{c}\text { No } \\
\text { So } \\
\text { al }\end{array}$ & $\begin{array}{c}\text { Mema } \\
\text { hami } \\
\text { Masal } \\
\text { ah }\end{array}$ & $\begin{array}{c}\text { Jenis Kesalahan } \\
\text { rmasi }\end{array}$ & $\begin{array}{c}\text { Ketera } \\
\text { mpilan } \\
\text { Proses }\end{array}$ & $\begin{array}{c}\text { Penul } \\
\text { isan } \\
\text { jawa } \\
\text { ban }\end{array}$ \\
\hline 1. & 3 & 3 & 4 & 3 \\
\hline 2. & 1 & 2 & 1 & 2 \\
\hline 3. & 1 & 2 & 1 & 2 \\
\hline 4. & 2 & 4 & 4 & 3 \\
\hline $\mathbf{5 .}$ & 1 & 2 & 2 & 2 \\
\hline Rata & 1,6 & 2,6 & 2,4 & 2,4 \\
\hline rata: & & & & \\
\hline
\end{tabular}

\section{Deskripsi:}

Berdasarkan hasil pekerjaan subjek 5 terlihat bahwa subjek 5 mengalami kesulitan mengerjakan soal nomer 2, 3 dan 5. Pada soal nomor 2, 3 dan 5 kesulitannya dipengaruhi oleh subjek 5 belum bisa memahami soal dengan baik sehingga subjek 5 tidak mampu menyebutkan informasi yang diketahui dari soal. Subjek 5 juga salah dalam menentukan rumus yang akan digunakan untuk menyelesaikan soal sehingga jawabannya tidak tepat. Selain itu 
subjek 5 juga tidak teliti dalam menjawab soal sehingga banyak jawaban yang kurang tepat.

Table 7. Hasil analisis soal HOTS dengan panduan Newman subjek keenam

\begin{tabular}{llccc}
\hline $\begin{array}{c}\text { No } \\
\text { So } \\
\text { al }\end{array}$ & \multicolumn{4}{c}{ Jenis Kesalahan } \\
\cline { 2 - 5 } & $\begin{array}{l}\text { Mema } \\
\text { hami } \\
\text { masal } \\
\text { ah }\end{array}$ & $\begin{array}{c}\text { Transfo } \\
\text { rmasi }\end{array}$ & $\begin{array}{c}\text { Ketera } \\
\text { mpilan } \\
\text { Proses }\end{array}$ & $\begin{array}{c}\text { Penul } \\
\text { isan } \\
\text { jawa } \\
\text { ban }\end{array}$ \\
\hline 1. & 2 & 3 & 4 & 3 \\
\hline $\mathbf{2 .}$ & 1 & 1 & 1 & 2 \\
\hline 3. & 2 & 4 & 2 & 2 \\
\hline $\mathbf{4 .}$ & 1 & 2 & 2 & 2 \\
\hline 5. & 1 & 2 & 2 & 2 \\
\hline $\begin{array}{l}\text { Rata } \\
\text { rata: }\end{array}$ & 1,4 & 2,4 & 2,2 & 2,2 \\
\hline Destips & & & & \\
\hline
\end{tabular}

Deskripsi:

Berdasarkan hasil pekerjaan subjek 6 terlihat bahwa subjek 6 mengalami kesulitan mengerjakan soal nomer 2, 4 dan 5. Pada soal nomor 2, 4 dan 5 kesulitannya dipengaruhi oleh subjek 6 belum bisa memahami soal dengan baik sehingga subjek 6 belum mampu menentukan informasi yang diketahui dari soal yang mengakibatkan subjek 6 salah dalam menentukan rumus yang akan digunakan untuk menyelesaikan soal sehingga jawabannya tidak tepat. Selain itu subjek 6 juga tidak teliti dalam menjawab soal sehingga banyak jawaban yang kurang tepat.

Table 8. Hasil analisis soal HOTS dengan panduan Newman subjek ketujuh

\section{Jenis Kesalahan}

\begin{tabular}{lcccc}
\hline $\begin{array}{c}\text { No } \\
\text { So } \\
\text { al }\end{array}$ & $\begin{array}{c}\text { Mema } \\
\text { hami } \\
\text { Masal } \\
\text { ah }\end{array}$ & $\begin{array}{c}\text { Transfo } \\
\text { rmasi }\end{array}$ & $\begin{array}{c}\text { Ketera } \\
\text { mpilan } \\
\text { Proses }\end{array}$ & $\begin{array}{c}\text { Penul } \\
\text { isan } \\
\text { Jawa } \\
\text { ban }\end{array}$ \\
\hline 1. & 2 & 3 & 4 & 3 \\
\hline $\mathbf{2 .}$ & 1 & 1 & 1 & 2 \\
\hline 3. & 3 & 2 & 2 & 2 \\
\hline 4. & 4 & 2 & 2 & 2 \\
\hline 5. & 1 & 2 & 1 & 2 \\
\hline Rata & 2,2 & 2 & 2 & 2,2 \\
rata: & & & & \\
\hline
\end{tabular}

Deskripsi:

Berdasarkan hasil pekerjaan subjek 7 terlihat bahwa subjek 7 mengalami kesulitan mengerjakan soal nomer 2 dan 5 . Pada soal nomor 2 dan 5 kesulitannya dipengaruhi oleh subjek 7 belum bisa memahami soal dengan baik sehingga subjek 7 belum mampu menentukan informasi yang diketahui dari soal sehingga subjek 7 salah dalam menentukan rumus yang akan digunakan untuk menyelesaikan soal sehingga jawabannya tidak tepat.

Table 9. Hasil analisis soal HOTS dengan panduan Newman subjek kedelapan

\begin{tabular}{ccccc} 
No & \multicolumn{3}{c}{ Jenis Kesalahan } \\
So & Mema & Transfo & Ketera & Penul \\
al & hami & rmasi & mpilan & isan \\
& Masal & & Proses & Jawa \\
& ah & & & ban
\end{tabular}

\begin{tabular}{lllll} 
1. & 1 & 1 & 1 & 2 \\
\hline 2. & 1 & 1 & 1 & 2 \\
\hline 3. & 1 & 1 & 1 & 2 \\
\hline 4. & 1 & 1 & 1 & 2 \\
\hline 5. & 1 & 1 & 1 & 2 \\
\hline $\begin{array}{l}\text { Rata } \\
\text { rata: }\end{array}$ & 1 & 1 & 1 & 2
\end{tabular}

Deskripsi: 
Berdasarkan hasil pekerjaan subjek 8 terlihat bahwa subjek 8 mengalami kesulitan mengerjakan semua soal. Kesulitannya dipengaruhi oleh subjek 8 belum bisa memahami soal dengan baik sehingga subjek 8 salah dalam menentukan rumus yang akan digunakan untuk menyelesaikan soal sehingga jawabannya tidak tepat.

Table 10. Hasil analisis soal HOTS dengan panduan Newman subjek ke sembilan

\begin{tabular}{|c|c|c|c|c|}
\hline No & & Jenis K & alahan & \\
\hline $\begin{array}{l}\text { so } \\
\text { al }\end{array}$ & $\begin{array}{c}\text { Mema } \\
\text { hami } \\
\text { Masal } \\
\text { ah }\end{array}$ & $\begin{array}{c}\text { Transfo } \\
\text { rmasi }\end{array}$ & $\begin{array}{c}\text { Ketera } \\
\text { mpilan } \\
\text { proses }\end{array}$ & $\begin{array}{c}\text { Penul } \\
\text { isan } \\
\text { Jawa } \\
\text { ban }\end{array}$ \\
\hline 1. & 1 & 1 & 1 & 2 \\
\hline 2. & 4 & 2 & 1 & 2 \\
\hline 3. & 2 & 4 & 2 & 2 \\
\hline 4. & 2 & 4 & 4 & 3 \\
\hline 5. & 1 & 2 & 1 & 2 \\
\hline $\begin{array}{l}\text { Rat } \\
\text { rata }\end{array}$ & & 1 & & \\
\hline
\end{tabular}

Deskripsi:

Berdasarkan hasil pekerjaan subjek 9 terlihat bahwa subjek 9 mengalami kesulitan mengerjakan soal nomer 1 dan 5. Pada soal nomor 1 dan 5 kesulitannya dipengaruhi oleh subjek 9 belum bisa memahami soal dengan baik sehingga subjek 9 salah dalam menentukan rumus yang akan digunakan untuk menyelesaikan soal sehingga jawabannya tidak tepat.
Table 11. Hasil analisis soal HOTS dengan panduan Newman Subjek kesepuluh

\begin{tabular}{lcccc}
\hline No & \multicolumn{4}{c}{ Jenis Kesalahan } \\
\cline { 2 - 5 } $\begin{array}{c}\text { al } \\
\text { al }\end{array}$ & $\begin{array}{c}\text { Mema } \\
\text { hami } \\
\text { Masal } \\
\text { ah }\end{array}$ & $\begin{array}{c}\text { Transfo } \\
\text { rmasi }\end{array}$ & $\begin{array}{c}\text { Ketera } \\
\text { mpilan } \\
\text { Proses }\end{array}$ & $\begin{array}{c}\text { Penul } \\
\text { isan } \\
\text { Jawa } \\
\text { ban }\end{array}$ \\
\hline 1. & 2 & 1 & 4 & 3 \\
\hline 2. & 1 & 1 & 1 & 2 \\
\hline 3. & 1 & 1 & 1 & 2 \\
\hline 4. & 1 & 1 & 1 & 2 \\
\hline 5. & 1 & 1 & 1 & 2 \\
\hline $\begin{array}{l}\text { Rata } \\
\text { rata: }\end{array}$ & 1,2 & 1 & 1,6 & 2,2 \\
\hline Deskripsi: & & & \\
\hline
\end{tabular}

Berdasarkan hasil pekerjaan subjek 10 terlihat bahwa subjek 10 mengalami kesulitan mengerjakan hamper semua soal. Kesulitannya dipengaruhi oleh subjek 10 belum bisa memahami soal dengan baik sehingga subjek 10 salah dalam menentukan rumus yang akan digunakan untuk menyelesaikan soal sehingga jawabannya tidak tepat.

Tabel 12. hasil analisis soal HOTS dengan panduan Newman

\begin{tabular}{ccccc}
\hline Sub & \multicolumn{5}{c}{ Jenis Kesalahan } \\
jek & $\begin{array}{c}\text { Mem } \\
\text { ahami } \\
\text { Masal } \\
\text { ah }\end{array}$ & $\begin{array}{c}\text { Trans } \\
\text { fortas } \\
\text { i }\end{array}$ & $\begin{array}{c}\text { Ketera } \\
\text { mpilan }\end{array}$ & $\begin{array}{c}\text { Penulisan } \\
\text { Proses }\end{array}$ \\
& & & \\
\hline $\mathbf{1}$ & 3,2 & 3,2 & 3,2 & 3,2 \\
\hline $\mathbf{2}$ & 3,4 & 3,2 & 2,8 & 2,6 \\
\hline $\mathbf{3}$ & 2,8 & 2 & 1,8 & 2,2 \\
\hline $\mathbf{4}$ & 3,4 & 3,2 & 2,2 & 2,2 \\
\hline $\mathbf{5}$ & 1,6 & 2,6 & 2,4 & 2,4 \\
\hline $\mathbf{6}$ & 1,4 & 2,4 & 2,2 & 2,2 \\
\hline $\mathbf{7}$ & 2,2 & 2 & 2 & 2,2 \\
\hline
\end{tabular}




\begin{tabular}{ccccc}
\hline $\mathbf{8}$ & 1 & 1 & 1 & 2 \\
\hline $\mathbf{9}$ & 2 & 2,6 & 1,8 & 2,2 \\
\hline $\mathbf{1 0}$ & 1,2 & 1 & 1,6 & 2,2 \\
\hline $\begin{array}{c}\text { Jum } \\
\text { lah }\end{array}$ & 22,2 & 23,2 & 21 & 23,4 \\
\hline $\begin{array}{c}\text { Rat } \\
\text { a- } \\
\text { rata }\end{array}$ & 2,22 & 2,32 & 2,1 & 2,34 \\
\hline
\end{tabular}

Deskripsi:

Berdasarkan hasil analisis kesulitan siswa dalam menyelesaikan soal HOTS materi bilangan bulat dengan panduan jenis kesalahan Newman diketahui bahwa ratarata siswa masih mengalami kesulitan dalam menyelesaikan soal HOTS materi bilangan bulat. Jenis kesalahan Newman sendiri terdiri dari memahami masalah, transformasi, keterampilan proses dan penulisan jawaban. Dari hasil/analisis jawaban siswa seperti yang tertera pada table di atas menunjukkan bahwa pada jenis kesalahan memahami masalah dalam soal didapat rata-rata 2,22, sementara untuk jenis kesalahan tranformasi rata-rata 2,32, untuk jenis kesalahan keterampilan proses didapat rata-rata 2,1 dan pada jenis kesalahan penulisan jawaban rata-rata 2,34. Dari data tersebut menunjukkan bahwa siswa paling banyak mengalami kesulitan dalam memahami masalah dan keterampilan proses.

Temuan tersebut sejalan dengan hasil wawancara yang dilakukan peneliti dengan siswa dimana kebanyakan dari siswa kurang mampu memahami soal dengan baik selain itu siswa juga kurang teliti saat mengerjakan soal sehingga dalam proses perhitungan sering terjadi kesalahan yang mengakibatkan jawaban atau hasil yang didapat kurang tepat.

$\begin{array}{rrr} & \text { Bedasarkan hasil wawancara } \\ \text { dengan guru mengenai kesulitan }\end{array}$
menyelesaikan soal HOTS materi bilangan bulat diketahui bahwa siswa sebenarnya sudah mengalami kesulitan dalam memahami materi bilangan bulat, apalagi soal HOTS dimana siswa dituntut untuk berpikir secara kritis sehingga tingkat kesulitan siswa dalam memahami masalah yang terdapat dalam soal lebih tinggi. Hal ini mengakibatkan siswa tidak mampu menyelesaikan soal HOTS materi bilangan bulat dengan baik.

Jadi dapat diketahui bahwa siswa kelas IV SDN Gunungsari 1 Rembang mengalami kesulitan menyelesaikan soal HOTS materi bilangan bulat. Hal ini disebabkan karena siswa tidak mampu memahami soal dengan baik sehingga siswa kesulitan untuk menentukan rumus atau teori yang sesuai dengan yang ditanyakan oleh soal. Hal ini mengakibatkan siswa mengalami banyak kesalahan dalam proses perhitungan yang mengakibatkan jawaban siswa tidak tepat. 


\section{Kesimpulan}

Berdasarkan hasil analisis menggunakan panduan jenis kesalahan Newman dapat diperoleh kesimpulan bahwa kesulitan yang dialami siswa kelas IV SDN 1 Gunungsari dalam menyelesaikan soal HOTS materi bilangan bulat yaitu siswa tidak mampu dalam memahami soal dengan baik sehingga siswa kesulitan dalam mengaplikasikan rumus atau teori yang tepat untuk menyelesaikan soal HOTS materi bilangan bulat yang mengakibatkan jawaban yang diperoleh siswa kurang tepat. Berdasarkan hasil wawancara dengan guru diketahui bahwa alasan siswa mengalami kesulitan dalam menyelesaikan soal HOTS materi bilangan bulat sendiri karena pada dasarnya materi bilangan bulat sudah sulit untuk dipahami siswa. Apalagi tipikal soal HOTS yang menuntut siswa untuk berpikir secara kritis dan harus bisa memahami isi soal dengan baik agar siswa mampu menetukan rumus secara tepat. Hal itu membuat siswa lebih kesulitan dalam menyelesaikan soal HOTS materi bilangan bulat.

Saran yang diajukan berdasarkan simpulan di atas yaitu:

1. Bagi peneliti

Peneliti sebaiknya melakukan penelitian dengan mengumpulakn data yang proporsional. Data yang dikumpulkan secara proporsional akan memberikan tingkat kevalidan yang tinggi. Permasalahan yang dialami dilapangan harus segera diatasi agar penelitian berjalan dengan lancar.

2. Bagi guru

Guru harus mampu mendeteksi permasalahan pembelajaran yang terjadi di kelasnya. deteksi dini terhadap sebuah permasalahan akan memudahkan dalam penyelesaiannya. Faktor-faktor yang mempengaruhi terjadinya sebuah permasalahan harus dikenali oleh guru. Selanjutnya guru harus mencarikan solusi terbaik agar sebuah permasalahan pembelajaran dapat teratasi.

3. Bagi peserta didik

Peserta didik harus serius dalam mengukuti pembelajaran yang diselenggarakan oleh guru di sekolah. Bimbingan dan arahan dari guru juga harus diperhatikan dan dilaksanakan. Tanpa arahan dan bimbingan dari guru peserta didik akan mengalami kesulitan belajar.

4. Bagi sekolah

Sekolah melalui Kepala Sekolah harus mempunyai kepedulian dalam meningkatkan kompetensi para guru. Guru harus meningkatkan kompetensinya terutama dalam hal kemampuan mengatasi permasalahan pembelajaran. Salah satu langkah yang 
dapat dilakukan adalah meningkatkan kemampuan membuat media pembelajaran yang menarik bagi siswa.

\section{Daftar Pustaka}

Anderson, L.W., dan Krathwohl, D.R. 2015. Kerangka Landasan untuk Pembelajaran, Pengajaran, dan Asesmen Revisi Taksonomi Pendidikan Bloom. Terjemahan Agung Prihantoro. Yogyakarta Pustaka Belajar.

Ariyana, Yoki dkk. 2019. Buku Pegangan Pembelajaran Beorientasi Pada Keterampilan Berpikir Tingkat Tinggi. Direktorat Jenderal Guru dan Tenaga Kependidikan .Kementerian Pendidikan dan Kebudayaan.

Badriyah, Nunuk dkk. 2020. Analisis kesulitan belajar siswa dalam menyelesaikan soal cerita matematika pada materi pecahan kelas III SDN Lamper Tengah 02. Pedagogic jurnal Pendidikan, maret 2020, volume 15 nomor $1,(10-15)$

Direktorat Pembina Sekolah Dasar. 2011.

Standar Kompetensi dan

Kompetensi Dasar Sekolah Dasar/

Madrasah Ibtidaiyah Kelas IV.
Jakarta: Kementrian Pendidikan Nasional

Eko, Jalil, dan Faisol. 2019. Nilai-Nilai Pendidikan Islam Dalam Film Animasi Nussa Dan Rara Karya Aditya Triantoro. Jurnal. Malang

Nariyah. (2016). “Analisis KesulitanKesulitan Dalam Menyelesaikan Soal Uraian Pokok Bahasan Bilangan Bulat Kelas IV SD Negeri Segugus Dewi Sartika Kecamatan Tegal Selatan". Skripsi. UNNES.

Soegeng Ysh, A.Y. 2016. Landasan Pendidikan. Yogyakarta. Magnum Pustaka Utama.

Susanto, Ahmad. 2013. Teori Belajar \& Pembelajaran di Sekolah Dasar. Jakarta: Prenadamedia Group.

Undang-Undang Republik Indonesia Nomor 20 Tahun 2003 tentang Sistem Pendidikan Nasional

W. Conklin \& J. Manfro. 2012. Higher order thinking skills to develop 21st century learners. Shell Education Publishing, Inc. Huntington.

Wardhana, M. Yusuf \& Silvia Trisnawati. 2016. Model Debat Aktif dan Media Dadu Kuis Untuk Mengembangkan Motivasi Belajar dan Keterampilan 
Berpikir Kritis Siswa SD. Malih

Peddas. Vol 6 No 2.

Zaini, Muhammad. 2015. "Hasil Belajar dan Keterampilan Berpikir Tingkat Tinggi Siswa SMA pada
Pembelajaran

Biologi

Menggunakan Model Pembelajaran

Berdasarkan Masalah”. Jurnal, Vol.20, No.207. (online). (Tersedia pada http://eprints.unlam.ac.id. diakses pada 5 Mei 2018)

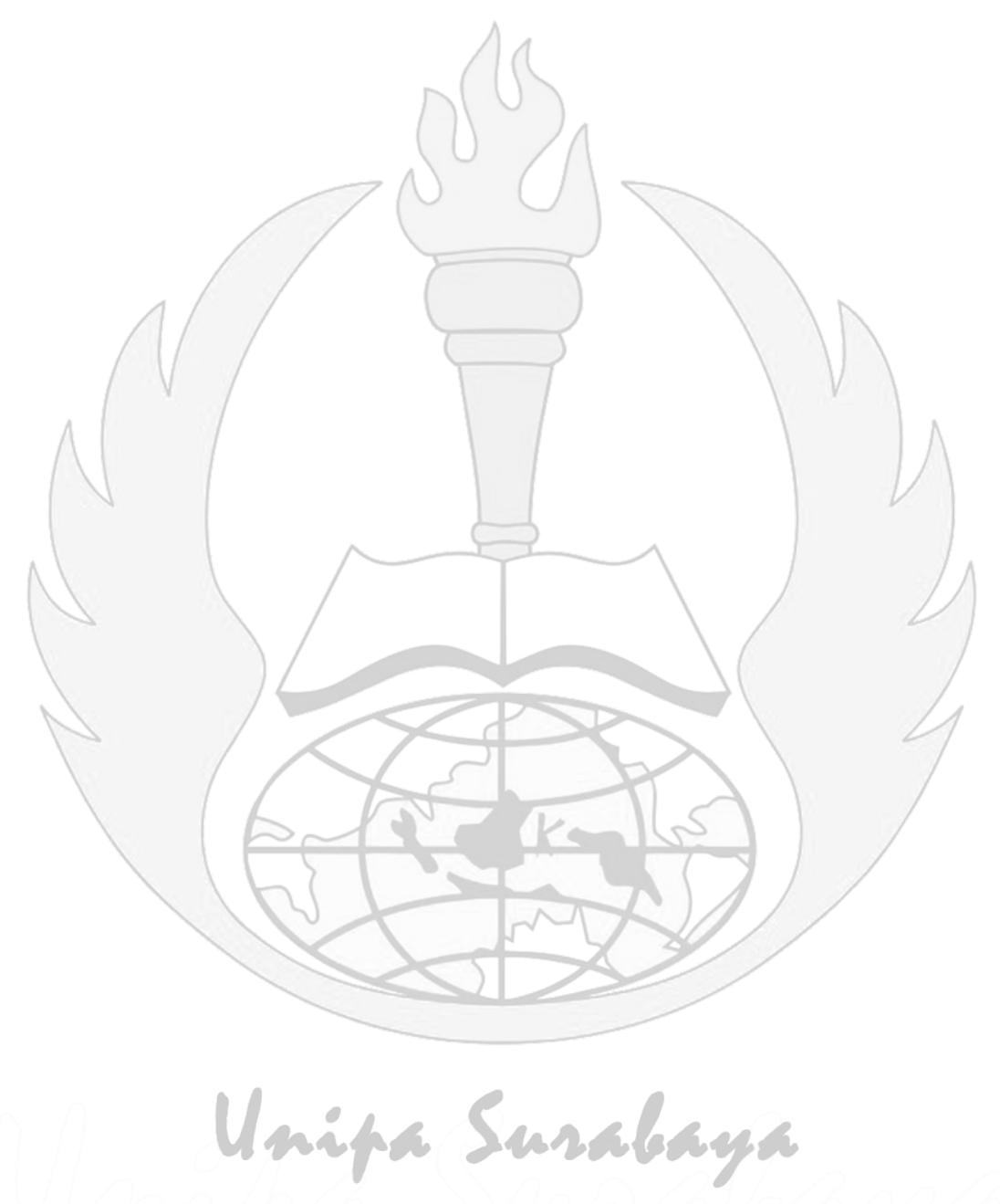

